University of Nebraska - Lincoln

DigitalCommons@University of Nebraska - Lincoln

Faculty Papers and Publications in Animal

Science

Animal Science Department

March 1983

\title{
INDEX SELECTION AND FEED INTAKE RESTRICTION IN SWINE. II. EFFECT ON ENERGY UTILIZATION
}

\author{
Erik R. Cleveland \\ University of Nebraska-Lincoln \\ R. K. Johnson \\ University of Nebraska-Lincoln, rjohnson5@unl.edu \\ R. W. Mandigo \\ University of Nebraska-Lincoln, rmandigo1@unl.edu \\ E. R. Peo Jr. \\ University of Nebraska-Lincoln
}

Follow this and additional works at: https://digitalcommons.unl.edu/animalscifacpub

Part of the Animal Sciences Commons

Cleveland, Erik R.; Johnson, R. K.; Mandigo, R. W.; and Peo, E. R. Jr., " INDEX SELECTION AND FEED INTAKE RESTRICTION IN SWINE. II. EFFECT ON ENERGY UTILIZATION" (1983). Faculty Papers and Publications in Animal Science. 28.

https://digitalcommons.unl.edu/animalscifacpub/28

This Article is brought to you for free and open access by the Animal Science Department at DigitalCommons@University of Nebraska - Lincoln. It has been accepted for inclusion in Faculty Papers and Publications in Animal Science by an authorized administrator of DigitalCommons@University of Nebraska - Lincoln. 


\title{
INDEX SELECTION AND FEED INTAKE RESTRICTION IN SWINE. II. EFFECT ON ENERGY UTILIZATION ${ }^{1}$
}

\author{
Erik R. Cleveland $^{2}$, R. K. Johnson ${ }^{3}$, R. W. Mandigo ${ }^{3}$ and E. R. Peo, Jr. ${ }^{3}$ \\ University of Nebraska, Lincoln 68583
}

\begin{abstract}
Summary
Fifty-three index select and control line barrows were randomly assigned to three feeding levels at $83 \mathrm{~d}$ of age. They were slaughtered at approximately $188 \mathrm{~d}$ of age to determine the effects of index selection (for increased average daily gain and decreased backfat) and level of feed intake on energy utilization. During the trial, the feed intake levels were twice daily to appetite (AP), once daily feeding of $91 \%$ of appetite (AP91) or once daily feeding of $82 \%$ of appetite (AP82) intake. The metabolizable energy intake required per kilogram of edible lean deposited (Mcal $/ \mathrm{kg}$ ) was reduced $(P<.05)$ by restricting intake and was lower $(\mathrm{P}<.01)$ for index than for control barrows [index: 25.6 (AP), 23.3 (AP91) and 25.3 (AP82) vs control: 31.1 (AP), 27.5 (AP91) and 28.1 (AP82)]. However, intake restriction and index selection increased $(P<.05)$ the energy lost per unit of retained energy (index: $1.33,1.45$ and 1.53 vs control: $1.24,1.29$ and 1.34). The index line had a higher $(P<.05)$ maintenance requirement than the control line when expressed unit of weight $\left(\mathrm{kg}^{\cdot 75}\right)^{-1}$. day $^{-1}$, but the difference was less when expressed unit of lean $\left(\mathrm{kg}^{\cdot 83}\right)^{-1} \cdot \mathrm{day}^{-1}$. The energy cost of protein deposition varied from 9.02 to $11.25 \mathrm{kcal} / \mathrm{g}$, while the energy cost of fat deposition ranged from 12.73 to 12.86 $\mathrm{kcal} / \mathrm{g}$. Variation among animals in metabolizable energy intake was explained by variation in lean mass maintained and the quantity of protein and fat deposited. (Key Words: Swine, Index Selection, Intake, Energy Utilization.)
\end{abstract}

\footnotetext{
'Published as Paper No. 6868, Journal Ser., Nebraska Agr. Exp. Sta.

${ }^{2}$ Present address: Univ. of Georgia, Rural Development Center, Tifton 31793.

${ }^{3}$ Anim. Sci. Dept.
}

\section{Introduction}

Tess (1981) used simulation models and estimated that growing pigs consumed about $80 \%$ of the Mcal required to produce $1 \mathrm{~kg}$ of carcass lean; the other $20 \%$ was consumed by the breeding herd. Clearly, improving the efficiency of lean tissue growth rate would have a major impact on the overall efficiency of producing lean pork.

The results of direct selection in swine for food conversion ratio are discouraging (Dickerson and Grimes, 1947; Jungst et al., 1981), even though selection for improved food conversion ratio in chickens reduced the food to gain ratio (Pym and Nicholls, 1979) and improved the carcass lean to fat ratio (Pym and Solvyns, 1979). In swine, index selection for increased growth rate and decreased backfat has been effective (Fredeen et al., 1976; Ollivier, 1977; Vangen, 1979; Cleveland et al., 1982).

The objectives of this experiment were: 1) to examine the effects of index selection for increased average daily gain and decreased backfat on energy utilization, 2) to examine the effects of daily intake restrictions on energy utilization and 3) to obtain estimates of the energy costs of maintenance, fat deposition and protein deposition in swine.

\section{Materials and Methods}

Experimental Procedure. A total of 86 index select and control line barrows were used. Both lines were derived from the Nebraska Gene Pool population. The index line was selected for six generations for an index of average daily gain and backfat, and the control line replacements were selected at random (Cleveland et al., 1982).

Fifty-three barrows were housed in an environmentally controlled individual feeding unit at a mean age of $82.8 \mathrm{~d}(\mathrm{SD}=4.4 \mathrm{~d})$, while 33 littermate barrows were slaughtered to 
establish initial body composition of the lines. Test pigs were randomly assigned to three feeding levels; twice daily feeding to appetite (AP), once daily feeding of $91 \%$ of appetite intake (AP91) and once daily feeding of $82 \%$ of appetite intake (AP82). They received a 16\% protein corn-soybean meal diet during the $105-\mathrm{d}$ (SD $=3.1 \mathrm{~d}$ ) test peiod. Weekly feed intake was recorded. Body composition was obtained at slaughter. Further details of the experiment and the body composition data are given in the first paper in this series (Cleveland et al., 1983).

Energy Digestibility Determination. The amount of digestible energy consumed by each barrow was calculated from the digestible energy percentage (DE\%) and the gross energy (GE) of the feed. Chromic sesquioxide (inert indicator) was mixed in the diet $(.5 \%)$ and fed to pigs weighing $59.8 \pm .6 \mathrm{~kg}$ and again $1 \mathrm{wk}$ before slaughter. After $4 \mathrm{~d}$ on the mixed diet, two fecal and two feed samples were collected from each pig. Samples were collected on two different days, pooled and frozen.

Chromium percentage in fecal and feed samples was determined by use of an atomic absorption spectrophotometer ${ }^{4}$ by the methods described by Williams et al. (1962). The GE of the feed was determined using an oxygen bomb calorimeter ${ }^{5}$ by the methods described by Parr Instrument Company (1978). Chromium levels and GE were adjusted to a dry matter (DM) basis as follows:

$$
\text { Value on DM basis }=\text { value } \cdot \mathrm{DM} \%^{-1} \cdot 100^{-1} \text {, }
$$

where,

value $=$ chromium percentage or GE value, and

$\mathrm{DM} \%=$ dry matter percentage as calculatd by AOAC (1975) methods.

Digestibility percentage (DIG\%) was calculated using the following formulas (Church, 1976):

$$
\left(100 \times \frac{\text { chromium } \% \text { in feed }}{\text { chromium } \% \text { in feces }} \times \frac{\text { fecal GE }}{\text { feed GE }}\right) .
$$

\footnotetext{
${ }^{4}$ Manufactured by Perkin-Elmer, Norwald, CT 06856.

${ }^{5}$ Manufactured by Parr Instrument Co., Moline, IL 61265.

${ }^{6}$ Manufactured by Tecator, Herndon, VA 22070.
}

Protein levels in the feed were determined using a Keltec apparatus ${ }^{6}$ by the methods described by AOAC (1980). On a DM basis, the feed contained mean values of $4.37 \mathrm{kcal} \mathrm{GE} / \mathrm{g}$ and $18.24 \%$ crude protein.

Data Analyses. Digestibility of the diet was calculated at a weight of approximately $60 \mathrm{~kg}$ $(\mathrm{SD}=4.1 \mathrm{~kg})$ and an age of $182 \mathrm{~d}(\mathrm{SD}=3.7 \mathrm{~d})$ for each pig. The mean weight at the $182 \mathrm{~d}$ determination was $91 \mathrm{~kg}(\mathrm{SD}=13.2 \mathrm{~kg})$. For each collection period, DIG\% was fitted to a model with the effects of line, feeding level, line $x$ feeding level and pig weight (WT) at the time of collection. No effects were significant. The data from the two collection periods were combined and fitted to a model with the fixed effects of line, feeding level, line $x$ feeding level and the linear and quadratic effects of WT. Only the linear effect of WT was significant, so all data were combined and DIG\% was regressed on WT. This regression coefficient was used as follows to estimate the digestibility of the diet at the midweight of each pig,

$$
\text { DIG\% }=79.3+(.0629 \times \text { midweight }) \text {. }
$$

The mean digestibility of the dict was $83.5 \%$ at the average midweight of all pigs, but was 82.8 and $85.3 \%$ for the first and second collection periods, respectively. From the total feed intake for each animal (FI) and the average DM of the feed $(86.1 \%)$, the digestible energy intake $\left(\mathrm{DE}_{\mathrm{I}}\right)$ was calculated for each animal as:

$$
\mathrm{DE}_{I}=\mathrm{FI} \times .86 \times 4.37 \times \frac{\mathrm{DIG} \%}{100}, \mathrm{kcal} .
$$

The $\mathrm{DE}_{\mathrm{I}}$ was converted to metabolizable energy intake $\left(M E_{I}\right)$ with the adjustment of Asplund and Harris (1969). The equation was:

$$
\begin{aligned}
& M E_{I}=\mathrm{DE}_{\mathrm{I}} \times[96-(.202 \times \\
& \text { crude protein } \%)] / 100, \mathrm{kcal} .
\end{aligned}
$$

On the ith day on test, metabolic body size $\left(\mathrm{WT}^{*}{ }_{1}^{75}\right)$ was estimated as:

$$
\begin{aligned}
\mathrm{WT}^{\cdot}{ }_{\mathrm{i}} & =[(\mathrm{i} \times \text { average daily gain })+ \\
& \text { initial weight }] \cdot{ }^{75} .
\end{aligned}
$$

The metabolic weight maintained over the test period was estimated by summing WT $^{\circ}{ }_{1}^{75}$ over the number of test days $\left(\Sigma W^{*}{ }_{i}^{75}\right)$. Tess (1981) found that fasting heat production was closely related to total body lean weight $\left(\mathrm{kg}^{\cdot 83}\right)$. The 
amount of lean maintained on the ith day was also calculated as:

$$
\begin{gathered}
\text { Lean }{ }^{83}=[(\mathrm{i} \times \text { daily lean gain })+ \\
\text { initial lean weight }] \cdot 83,
\end{gathered}
$$

and $\Sigma$ Lean ${ }^{83}$ gave the total lean weight maintained over the test period. Initial lean weight and daily lean gain were estimated from the composition of littermates at the beginning of the test and the final composition of test pigs (Cleveland et al., 1983).

The energy cost of maintenance $\left(b_{m}\right)$ was expressed per unit of metabolic weight $\left(\mathrm{kg}^{\cdot 75}\right)$ and per unit of lean weight $\left(\mathrm{kg}^{\cdot 83}\right)$ as:

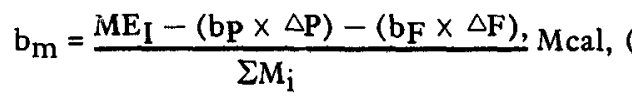

where,

$\Delta \mathbf{P}$ and $\Delta \mathrm{F}$ are weights of protein and fat, respectively, deposited during the trail (Cleveland et al., 1983) and $\Sigma M_{i}=\Sigma W_{T}^{\cdot 75}$ or $\Sigma$ Lean ${ }_{i}^{83}$.

Pullar and Webster (1977) estimated the energy cost of protein (bp) and fat $\left(b_{F}\right)$ deposition to be 12.6 and $12.8 \mathrm{kcal} / \mathrm{g}$, respectively, for rats. Corresponding values for swine have been estimated as 10.5 (bP) and 16.16 (bF) kcal/g (Tess, 1981). The coefficients from both experiments were used for bP and $b_{F}$ in equation 8 and two values of $b_{m}$ were calculated for each pig.

The total retained energy in the body was estimated as:

$$
\mathrm{RE}=(5.7 \times \Delta \mathrm{P})+(9.5 \times \Delta \mathrm{F}) .
$$

Gross energy values for protein $(5.7 \mathrm{kcal} / \mathrm{g})$ and fat $(9.5 \mathrm{kcal} / \mathrm{g})$ were reported by van Es (1977). The energy loss (EL) was then expressed as the difference between $M E_{I}$ and $R E$.

Measures of efficiency were expressed as ratios of the various energy utilization values to weight gain and were fitted to a model that included the effects of line, feeding level, line $x$ feeding level and initial test weight. The average difference between lines, and orthogonal contrasts among feeding levels of $1 / 2(A P+$ AP91) vs AP82 and AP vs AP91 were calculated. The interaction of these contrasts with line was also tested.

Simultaneous estimates of $b_{m}, b_{p}$ and $b_{F}$ were calculated within each line from the equation:

$$
M E_{I}=b_{M}\left(\Sigma M_{1}^{q}\right)+b_{P} \triangle P+b_{F} \Delta F .
$$

Four different definitions of mass $\left(M_{i}^{\mathrm{a}}\right)$, as defined by Tess (1981), were used. These were Lean $\cdot{ }_{i}^{83}$, Lean $2 \cdot \underset{i}{.85}$, Water $\cdot{ }_{i}^{83}$ and Protein $\cdot \underset{i}{75}$. Lean was defined as the weight of water, protein and ash and Lean2 was defined as slaughter weight minus fat weight. The value of each definition of mass on the ith day was calculated as:

$$
\begin{gathered}
M_{i}^{\mathrm{a}}=(\mathrm{i} \times \text { daily gain of mass }+ \\
\text { initial mass weight })^{\mathrm{a}} \text {. }
\end{gathered}
$$

The daily gain and the initial weight of each mass function are given by Cleveland et al. (1983).

This approach to derive estimates of $b_{M}, b_{P}$ and $b_{F}$ assumes that $M E_{I}$ is a dependent variable and $\Delta \mathrm{P}$ and $\Delta \mathrm{F}$ are independent variables. However, feed intake was restricted, and $M E_{I}$ does not, therefore, meet a strict definition of a dependent regression variable.

Equations developed by Tess (1981) were used to predict $M E_{I}$ for the barrows of this study. The correlation between predicted $M E_{I}$ and observed $M E_{I}$ was calculated to determine the degree to which variation in $M E_{I}$ in the present study could be predicted by variation in rate and composition of growth. The four largest $\mathbf{R}^{2}$ equations from the research of Tess (1981) are:

$$
\begin{aligned}
& M E_{I}=.13\left(\Sigma \text { Lean }^{\circ}{ }_{i}^{83}\right)+10.5 \Delta P+ \\
& 16.16 \triangle \mathrm{F} \text {; } \\
& M E_{I}=.116\left(\Sigma \text { Lean }_{i}^{\circ 55}\right)+10.95 \Delta P+ \\
& 16.22 \triangle \mathrm{F} \text {; } \\
& M E_{I}=.166\left(\Sigma W_{a t e r}{ }_{i}^{83}\right)+10.07 \Delta P+ \\
& 16.19 \triangle \mathrm{F} \text {; } \\
& M E_{1}=.524\left(\Sigma \text { Protein }_{i}^{\circ}{ }_{19}\right)+ \\
& 11.04 \triangle \mathrm{P}+16.09 \triangle \mathrm{F} \text {. }
\end{aligned}
$$

\section{Results}

Line means for various ratios expressing the efficiency of energy utilization are presented in table 1 . The interaction of line and feeding level was not significant for any trait.

Index barrows used significantly less feed per unit of live weight gain and per unit of lean gain than control barrows. They also were more efficient for the ratios of metabolizable energy intake to lean gain. This is partly due to the fact that lean has more water and is of lower energy density than fat. Index barrows had a 


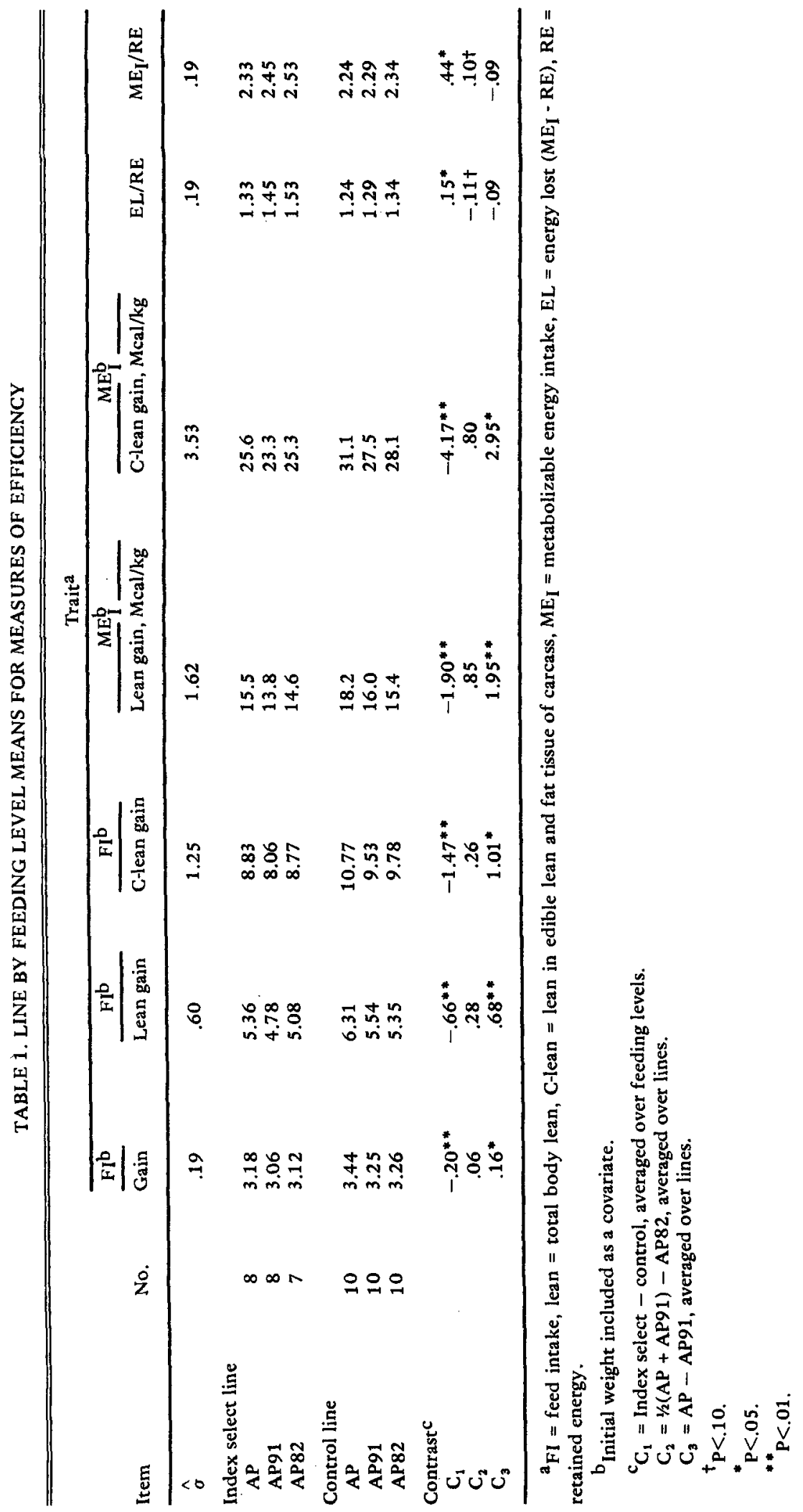


faster rate of lean growth and a slower rate of fat growth than control barrows (Cleveland et al., 1983).

Barrows fed the AP91 intake level were more efficient, both in live weight gain and in lean gain, than barrows fed the AP intake level. There was little difference in efficiency between barrows on the AP91 and AP82 intake levels. This may be explained by the fact that restricting intake from AP to AP91 levels significantly reduced daily fat deposition, but had very little effect on rate of protein deposition. However, the second level of restriction (AP91 to AP82) resulted in virtually the same relative reduction in both lean and fat growth (Cleveland et al., 1983). Restricting intake also reduced average daily maintenance weight. This should have improved efficiency, but was probably offset by the fact that intake above maintenance was also reduced and a higher percentage of daily intake was used for maintenance.

Severe feed restrictions will have an unfavorable effect on efficiency of growth (Vanschoubroeck et al., 1967). Barrows on the AP82 regimen, especially the index line, did not receive an adequate daily protein intake (Cleveland et al., 1983). Other nutrients also may have been limiting. Efficiency was generally poorer for index pigs fed at the AP82 intake level than for those fed at the AP91 level.

Although index selection affected both rate and composition of growth, total retained energy $(\mathrm{RE}=5.7 \times \Delta \mathrm{P}+9.5 \times \triangle \mathrm{F})$ was not significantly different between the lines. Total $\mathrm{RE}$ averaged $2,575 \pm 64$ and $2,689 \pm 57 \mathrm{kcal} / \mathrm{d}$ for index and control pigs, respectively. However, energy loss $\left(E L=M E_{I}-R E\right)$ was $3,664 \pm$ $70 \mathrm{kcal} / \mathrm{d}$ for index pigs and $3,427 \pm 61 \mathrm{kcal} / \mathrm{d}$ for the control line. Energy loss/unit of retained energy (EL/RE) was significantly higher for the index pigs, indicating that they used a higher percentage of the daily $M E_{I}$ for maintenance than did control pigs. This is probably explained by variation in weight of lean that was maintained per day. Tess (1981) found that fat and lean lines differed in fasting heat production. However, variation in efficiency of utilization of intake above maintenance for lean and fat deposition would also cause variation in daily maintenance requirements. Restricting intake decreased intake above maintenance and the effect, although not significant, was to increase the energy loss/unit of retained energy.

When the energy costs of fat and protein deposition were assumed to be $\mathbf{1 2 . 6}$ and 12.8 $\mathrm{kcal} / \mathrm{g}$ (Pullar and Webster, 1977), maintenance requirements $\left(\mathrm{Mcal} / \Sigma \mathrm{WT}^{\circ}{ }_{\mathrm{i}}^{75}\right.$ ) estimated from equation 8 were not significantly affected by either line or feeding level (table 2). However, if the energy costs of protein and fat deposition are 10.50 and $16.16 \mathrm{kcal} / \mathrm{g}$ (Tess, 1981), the maintenance requirement of the index line was $.01 \mathrm{Mcal} / \Sigma \mathrm{WT} \cdot{ }_{\mathrm{i}}^{75}$ higher than for that of the control line. The difference between the lines was less when daily maintenance requirement was expressed per unit of lean weight

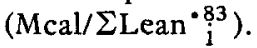

Tess (1981) estimates, because they were estimated from swine, seem more appropriate for estimating maintenance requirements. Sundst $\emptyset$ let al. (1979) and Tess (1981) reported that fat pigs produced less heat per unit of weight ${ }^{75}$ than did lean pigs. Also, Tess (1981) reported correlation coefficients of .94 and .95 between fasting heat production and lean mass at 17 and 24 wk of age, respectively. Their results and the results of the present study suggest that metabolizable energy for maintenance is higher for lean than for fat pigs.

Estimates of $b_{m}, b_{P}$ and $b_{F}$ obtained from solutions to equation 10 are presented in table 3. Within line estimates of bp were individually not significantly different from zero. However, the total protein deposited over the trial $(\Delta \mathrm{P})$ and the functions of lean mass $\left(M_{\mathrm{i}}\right)$ are quite highly correlated, and the partial regression of $M E_{I}$ on $\triangle P$ added little to the predictive value of the equation. Estimates of $b_{F}$ were less variable than those for $b_{P}$, indicating that estimates of $b_{P}$ are more sensitive to the estimate of maintenance requirement than are estimates of bF. This dependency is most evident from comparisons of $b_{m}$ and $b_{p}$ for each line. For each definition of maintenance mass, $b_{m}$ is lower and $b_{P}$ higher for the select line than for the control line.

Averaged across lines and maintenance mass functions, estimates of $b_{P}$ and $b_{F}$ were $9.94 \pm$ 2.08 and $12.81 \pm .51 \mathrm{kcal} / \mathrm{g}$, respectively. Cleveland (1981) reviewed publications of data from 13 experiments that contained estimates of $b_{p}$ and $b_{F}$. The average values were 10.9 (bP) and $13.5\left(\mathrm{~b}_{\mathrm{F}}\right) \mathrm{kcal} / \mathrm{g}$. Estimates of $\mathrm{b}_{\mathbf{P}}$ ranged from $7.43 \mathrm{kcal} / \mathrm{g}$ (Burlacu et al., 1973) to $15.96 \mathrm{kcal} / \mathrm{g}$ (Kielanowski and Kotarbinska, 1970). The range for estimates of $b_{F}$ was 9.5 $\mathrm{kcal} / \mathrm{g}$ (Burlacu et al., 1976) to $16.16 \mathrm{kcal} / \mathrm{g}$ (Sharma and Young, 1970). There was more variation between experiments for estimates of 
TABLE 2. LINE BY FEEDING LEVEL MEANS FOR ENERGY COSTS OF MAINTENANCE (b $b)$ CALCULATED FROM LITERATURE ESTIMATES FOR ENERGY COSTS OF PROTEIN (bP) AND FAT $\left(b_{F}\right)$ DEPOSITIONa

\begin{tabular}{|c|c|c|c|c|c|c|c|c|c|c|}
\hline \multirow[b]{2}{*}{ Item } & \multirow[b]{2}{*}{$\sigma$} & \multicolumn{3}{|c|}{ Index select line } & \multicolumn{3}{|c|}{ Control } & \multicolumn{3}{|c|}{ Contrast $^{b}$} \\
\hline & & AP & AP91 & AP82 & $\mathbf{A P}$ & AP91 & AP82 & $\mathrm{C}_{1}$ & $\mathrm{C}_{2}$ & $\mathrm{C}_{3}$ \\
\hline No. & & 8 & 8 & 7 & 10 & 10 & 10 & & & \\
\hline $\mathrm{b}_{\mathrm{m}}^{\mathrm{c}}, \mathrm{Mcal} / \Sigma \mathrm{WT}_{\mathrm{i}}^{\cdot} \mathrm{7s}^{5}$ & .013 & .107 & .105 & .099 & .107 & .097 & .092 & .005 & .005 & .006 \\
\hline $\mathrm{b}_{\mathrm{m}}^{\mathrm{d}}, \mathrm{Mcal} / \Sigma \mathrm{WT}^{*}{ }_{\mathrm{i}}^{5}$ & .016 & .079 & .082 & .079 & .073 & .069 & .067 & $.010^{*}$ & -.000 & -.001 \\
\hline $\mathrm{b}_{\mathrm{m}}^{\mathrm{d}}$, Mcal $/ \Sigma$ Lean $_{i}{ }_{\mathrm{i}}^{83}$ & .016 & .078 & .079 & .077 & .075 & .069 & .067 & $.008 t$ & .001 & .003 \\
\hline
\end{tabular}

$a_{b_{m}}=\frac{M E_{I}-\left(b_{P} \Delta P\right)-\left(b_{F} \Delta F\right)}{\Sigma M_{i}}$. See text, equation 8.

${ }^{\mathrm{b}} \mathrm{C}_{1}=$ Index select line - control line, averaged over feeding levels.

$C_{2}=1 / 2(A P+A P 91)-A P 82$, averaged over lines.

$C_{3}=A P-A P 91$, averaged over lines.

$c_{b_{P}}=12.6$ and $b_{F}=12.8 \mathrm{kcal} / \mathrm{g}$ (Pullar and Webster, 1977).

$d_{b p}=10.50$ and $b_{F}=16.16 \mathrm{kcal} / \mathrm{g}$ (Tess, 1981).

$\dagger_{\mathbf{p}<.10}$.

${ }^{*} \mathrm{P}<.05$.

TABLE 3. REGRESSION ESTIMATES OF THE ENERGY COSTS OF MAINTENANCE (bm), PROTEIN DEPOSITION (bP) AND FAT DEPOSITION (bF) ${ }^{a}$

\begin{tabular}{|c|c|c|c|c|}
\hline $\mathrm{M}_{1}^{\mathrm{b}}$ & $\mathrm{b}_{\mathrm{m}}$ & bP & $\mathbf{b}_{\mathbf{F}}$ & $\mathrm{R}^{2}$ \\
\hline \multicolumn{5}{|l|}{ Index select line } \\
\hline 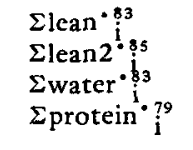 & $\begin{array}{l}.101(.029)^{c * *} \\
.090(.026)^{* *} \\
.129(.036)^{* *} \\
.386(.126)^{* *}\end{array}$ & $\begin{array}{l}10.50(6.91) \\
11.26(6.83) \\
10.03(6.88) \\
12.02(7.32)\end{array}$ & $\begin{array}{l}13.86(1.59)^{* *} \\
13.81(1.61)^{* *} \\
13.84(1.58)^{* *} \\
14.01(1.67)^{* *}\end{array}$ & $\begin{array}{l}.998 \\
.998 \\
.998 \\
.998\end{array}$ \\
\hline \multicolumn{5}{|l|}{ Control line } \\
\hline 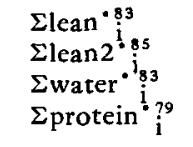 & $\begin{array}{l}.121(.029)^{* *} \\
.108(.026)^{* *} \\
.154(.036)^{* *} \\
.478(.110)^{* *}\end{array}$ & $\begin{array}{l}7.49(5.73) \\
8.05(5.73) \\
7.26(5.78) \\
8.73(5.43)\end{array}$ & $\begin{array}{l}12.70(1.62)^{* *} \\
12.74(1.64)^{* *} \\
12.71(1.62)^{* *} \\
12.65(1.61)^{* *}\end{array}$ & $\begin{array}{l}.998 \\
.997 \\
.997 \\
.997\end{array}$ \\
\hline \multicolumn{5}{|c|}{ Pooled within line } \\
\hline 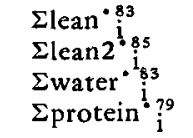 & $\begin{array}{l}.113(.020)^{* *} \\
.101(.018)^{* *} \\
.145(.025)^{* *} \\
.442(.080)^{* *}\end{array}$ & $\begin{array}{r}9.46(4.17)^{*} \\
10.03(4.16)^{*} \\
9.02(4.20)^{*} \\
11.25(4.07)^{* *}\end{array}$ & $\begin{array}{l}12.82(1.00)^{* *} \\
12.84(1.01)^{* *} \\
12.86(.99)^{* *} \\
12.73(1.04)^{* *}\end{array}$ & $\begin{array}{l}.998 \\
.998 \\
.998 \\
.992\end{array}$ \\
\hline
\end{tabular}

${ }^{a} E_{I}=b_{m}\left(\Sigma M_{j}\right)+b_{P} \Delta P+b_{F} \Delta F, k c a l / g$. See text, equation 10 .

$\mathrm{b}_{\text {Mass function for }} \mathrm{ME}_{\mathrm{m}}$.

${ }^{c}$ Values in parentheses are standard errors.

${ }^{*} \mathbf{P}<.05$.

${ }^{* *} \mathrm{P}<.01$. 
$b_{P}$ than for estimates of $b_{F}$ and Kielanowski (1965) has discussed possible explanations for this variability. Much of the variation probably was caused by the correlation between the estimates of the rate of protein synthesis and daily maintenance requirement. Errors in estimation of metabolizable energy for maintenance will lead to errors in estimates of the energy costs of protein synthesis.

The observed $M E_{I}$ and the $M E_{I}$ that was predicted from the four equations (equations 12 through 15 ) that were developed by Tess (1981) are compared in table 4. Observed $\mathrm{ME}_{\mathrm{I}}$ is from 117 to $136 \mathrm{Mcal}$ lower than predicted $M E_{I}$. The ambient temperature was kept at approximately $23.8 \mathrm{C}$ for the present experiment, while in the experiment reported by Tess (1981), ambient temperature was about 18.5 C. The temperature difference may be a large cause of the difference between observed and predicted $M E_{I}$, but feeding regimens were also different. The pigs of the experiment reported by Tess (1981) were fed ad libitum, while restricted feeding was used in the present experiment. Level of daily feed intake may affect maintenance requirement. Also, feed wastage should be less for restricted feeding than for ad libitum feeding.

Each of the above factors is expected to cause estimates of maintenance requirement to be lower for the pigs of this study than for those contributing to the estimates reported by Tess (1981). Estimates of $b_{m}$ (table 3 ) were 84 to $87 \%$ as large as those in the equations reported by Tess (1981). However, all correlations between observed and predicted $M E_{1}$ were high (.87 or larger). A high proportion of the variation among animals in $M E_{1}$ can be explained by variation in lean mass, or components of lean mass, being maintained per day and by the quantity of protein and fat being deposited. The equations developed by Tess (1981) provide a good fit to an independent data set, even though the experiments utilized different lines, environments and experimental procedures.

\section{Discussion}

Index selection for increased average daily gain and decreased backfat reduced the quantity of food required per unit of lean and live weight gain. The average difference between the index and control lines for food/gain was .20, which represents a change of -.033 units/ generation of selection. Other investigators have reported similar improvements in food conversion ratio from selection for increased average daily gain and decreased backfat. Changes per generation were -.037 (Ollivier, 1977), -.015 (Sather and Fredeen, 1978) and -.006 (Vangen, 1980).

The poor response to direct selection for food conversion ratio (Jungst et al., 1981) and the higher improvements obtained from index selection for growth rate and backfat raises

TABLE 4. LINE BY FEEDING LEVEL COMPARISONS OF ACTUAL AND PREDICTED ME I (MCAL)

\begin{tabular}{|c|c|c|c|c|c|c|c|c|c|}
\hline \multirow[b]{2}{*}{ Item } & \multirow[b]{2}{*}{$\mathrm{ME}_{\mathrm{I}}$} & \multicolumn{8}{|c|}{ Predicted $M E_{I}^{\mathrm{a}}$} \\
\hline & & $\mathbf{P}_{1}$ & $\mathbf{r}$ & $\mathbf{P}_{2}$ & $\mathbf{r}$ & $\mathbf{P}_{3}$ & $\mathbf{r}$ & $\mathbf{P}_{4}$ & $\mathbf{r}$ \\
\hline \multicolumn{10}{|c|}{ Index select line } \\
\hline $\begin{array}{l}\text { AP } \\
\text { AP91 } \\
\text { AP82 }\end{array}$ & $\begin{array}{l}750.5 \\
692.5 \\
572.1\end{array}$ & $\begin{array}{l}877.7 \\
822.9 \\
694.2\end{array}$ & $\begin{array}{l}.96 \\
.96 \\
.88\end{array}$ & $\begin{array}{l}876.3 \\
820.9 \\
691.9\end{array}$ & $\begin{array}{l}.96 \\
.96 \\
.87\end{array}$ & $\begin{array}{l}879.7 \\
823.9 \\
695.0\end{array}$ & $\begin{array}{l}.96 \\
.96 \\
.88\end{array}$ & $\begin{array}{l}871.5 \\
816.9 \\
689.1\end{array}$ & $\begin{array}{l}.95 \\
.96 \\
.87\end{array}$ \\
\hline \multicolumn{10}{|c|}{ Control line } \\
\hline $\begin{array}{l}\text { AP } \\
\text { AP91 } \\
\text { AP82 }\end{array}$ & $\begin{array}{l}734.5 \\
611.8 \\
568.8\end{array}$ & $\begin{array}{l}856.1 \\
741.9 \\
706.2\end{array}$ & $\begin{array}{l}.93 \\
.98 \\
.93\end{array}$ & $\begin{array}{l}854.4 \\
740.2 \\
704.2\end{array}$ & $\begin{array}{l}.93 \\
.98 \\
.93\end{array}$ & $\begin{array}{l}856.4 \\
742.3 \\
706.3\end{array}$ & $\begin{array}{l}.93 \\
.98 \\
.93\end{array}$ & $\begin{array}{l}855.1 \\
740.3 \\
704.8\end{array}$ & $\begin{array}{l}.93 \\
.98 \\
.94\end{array}$ \\
\hline
\end{tabular}

${ }^{\mathrm{a}}$ Equations from Tess (1981).

$P_{1}: M_{I}=.130\left(\Sigma\right.$ Lean $\left.^{\circ 3}\right)+10.5 \Delta P+16.16 \Delta F$.

$\mathrm{P}_{2}: M E_{1}=.116\left(\Sigma\right.$ Lean2 $\left.{ }^{15}\right)+10.95 \Delta \mathrm{P}+16.22 \Delta \mathrm{F}$.

$\mathrm{P}_{3}: \mathrm{ME}_{\mathrm{I}}=.166\left(\Sigma \mathrm{Water}^{\circ}\right)+10.07 \Delta \mathrm{P}+16.19 \Delta \mathrm{F}$.

$\mathrm{P}_{4}: \mathrm{ME}_{\mathrm{I}}=.524\left(\Sigma\right.$ Protein $_{\mathrm{i}}^{*}$ ) $+11.04 \Delta \mathrm{P}+16.09 \Delta \mathrm{F}$.

$\mathrm{r}=$ correlation coefficient between observed and predicted values. 
questions as to how food conversion ratio should be used in swine improvement programs. Index selection for increased average daily gain, decreased backfat and decreased food conversion ratio has improved the food to gain ratio by -.03 (M. Ellis and W. C. Smith, unpublished data) and -.025 (McPhee, 1979) units/ generation. However, changes in backfat, and particularly rate of gain, were considerably less than the changes for these traits in experiments selecting on an index of average daily gain and backfat.

Clearly, improved lean tissue food conversion should be a breeding objective. The present results, however, lead us to question the value of placing food conversion ratio in the selection index. In this light, the results of the British $\mathbf{P}_{i g}$ Improvement scheme are relevant (C. Smith, personal communication). The selection objectives included growth rate, food conversion ratio and carcass merit; and the selection index included growth rate, food conversion and carcass merit of the individual and(or) sibs. In standard measure, food conversion ratio received considerably more emphasis than the other traits. Estimated genetic changes per year were $5 \mathrm{~g} / \mathrm{d}$ (daily gain), -.027 units (food conversion ratio) and $.68 \%$ (carcass lean). Although no direct comparison can be made to improvements from selection for growth rate and backfat, the value of these improvements is considerable.

Index selection for growth and backfat increased daily maintenance requirement of growing pigs. This kind of selection also is expected to lead to increased mature size and higher maintenance costs of the breeding herd. An evaluation needs to be made of whether or not the improved efficiency in the growth of market pigs would be offset by any loss in efficiency from higher maintenance costs of the breeding herd. It is unlikely that differences found in the present experiment would materially affect breeding herd maintenance. Furthermore, swine breeding herd maintenance is only $20 \%$ of feed costs. There would have to be a large relative change in breeding herd maintenance for index selection not to be useful.

Restricting intake improved the efficiency of converting food energy to carcass lean, but rate of growth also was decreased. Barrows fed the AP91 intake level had a food conversion ratio that was .16 units lower (5\%) than barrows fed at the AP level. Average daily gain was $.063 \mathrm{~kg}$ less $(10 \%)$. Barrows growing over the interval of 36 to $100 \mathrm{~kg}$, performing at the levels of barrows in this study, would consume about 10 $\mathrm{kg}$ less feed, but require eight more feeding days if fed at the AP91 level compared with the AP level. Depending on the relationship of daily fixed costs to feed costs, this could be economically advantageous to the swine industry. Economic advantages will be greater in times of high feed costs and if value differences between pigs become more closely related to percentages of carcass lean.

\section{Literature Cited}

AOAC. 1975. Official Methods of Analysis (12th Ed.). Association of Official Analytical Chemist, Washington, DC.

AOAC. 1980. Official Methods of Analysis (13th Ed.). Association of Official Analytical Chemist, Washington, DC.

Asplund, J. M, and L. E. Harris. 1969. Metabolizable energy values for nutrient requirements for swine. Feedstuffs $41(14): 38$.

Burlacu, G., G. Baiu, D. Ionila, D. Moisa, V. Tascenco, J. Visan and J. Stoica. 1973. Efficiency of the utilization of the energy of food in piglets after weaning. J. Agr. Sci. (Camb.) 81:295.

Burlacu, G., M. Illiescu and J. Straui. 1976. Efficiency of energy utilization by growing pigs. In: $M$. Vermored (Ed.) Energy Metabolism of Farm Animals. European Assoc. Anim. Prod. Pub. No. 19. p 181.

Church, D. C. 1976. Digestive Physiology and Nutrition of Ruminants. Vol. I. Digestive Physiology (2nd Ed.). Oxford Press, Portland, OR.

Cleveland, E. R. 1981. The effect of lean growth selection and feed intake on composition and energy utilization in swine and correlated responses in carcass and reproductive traits from lean growth selection in swine. Ph.D. Dissertation, Univ, of Nebraska, Lincoln.

Cleveland, E. R., P. J. Cunningham and E. R. Peo, Jr. 1982. Selection for lean growth in swine. J. Anim. Sci. 54:719.

Cleveland, E. R., R. K. Johnson and R. W. Mandigo. 1983. Index selection and feed intake restriction in swine. I. Effect on rate and composition of growth. J. Anim. Sci. 56:560.

Dickerson, G. E. and J. C. Grimes, 1947. Effectiveness of selection for efficiency of gain in Duroc swine. J. Anim. Sci. 6:265.

Freeden, H. T., H. Mikami and A. Sather. 1976. Performance response to selection for growth rate and minimum fat in a pig population. Proc. 25th Annu. Natl. Poul. Breeders Roundtable, Kansas City, MO.

Jungst, S. B., L. L. Christian and D. L. Kuhlers. 1981. Response to selection for feed efficiency in individually fed Yorkshire boars. J. Anim. Sci. $53: 323$.

Kielanowski, J. 1965. Estimates of the energy cost of protein and fat deposition in growing animals. In : K. L. Blaxter (Ed.) Energy Metabolism. European Assoc. Anim. Prod. Pub. No. 11. p 13.

Kielanowski, J. and M. Kotarbinska. 1970. Further 
studies on energy metabolism in the pig. In: A. Schurch and C. Wenk (Ed.) Energy of Farm Animals. European Assoc. Anim. Prod. Pub. No. 13. p 145.

McPhee, C. P. 1979. Selection for efficient lean growth in pigs on high levels of feeding. Proc. Inaugural Conf. of Australian Assoc. Anim. Breeding and Genetics.

Ollivier, L. 1977. Dix ans d'une experience individuelle sur des verrats utilises en insemination artificielle. I. Responses observees sur des caracteres de croissance de carcasse et de qualite de viande. Ann. Genet. Sel. Anim. 9:375.

Parr Instrument Company. 1978. Instructions for the 1241 and 1242 adiabatic colorimeters. Parr Instrument Co., Moline, IL. Manual No. 153.

Pullar, J. D. and A.J.F. Webster. 1977. The energy cost of fat and protein deposition in the rat. Brit. J. Nutr. 37:355.

Pym, R.A.E. and P. J. Nichols. 1979. Selection for food conversion in broilers: Direct and correlated responses to selection for body-weight gain, food consumption and food conversion ratio. Brit. Poul. Sci. 20:73.

Pym, R.A.E. and A. J. Solvyns. 1979. Selection for food conversion in broilers: Body composition of birds selected for increased body-weight gain, food consumption and food conversion ratio. Brit. Poul. Sci. 20:87.

Sather, A. P. and H. T. Fredeen. 1978. Effect of selection for lean growth upon feed utilization of market hogs. Can. J. Anim. Sci. 58:285.

Sharma, V. D. and L. G. Young. 1970. The energy cost of protein and fat deposition in young pigs. J. Anim. Sci. 31:210 (Abstr.).

Sundst $\varnothing 1$, F., N. Standal and O. Vangen. 1979. Energy metabolism in lines of pigs selected for thickness of backfat and rate of gain. Acta Agr. Scand. 29:337.

Tess, M. W. 1981. Simulated effects of genetic change upon life-cycle production efficiency in swine and the effect of body composition upon energy utilization in the growing pig. Ph.D. Dissertation. Univ. of Nebraska, Lincoln.

van Es, A.J.H. 1977. The energetics of fat deposition during growth. Nutr. Metab. 21:88.

Vangen, O. 1979. Studies on a two trait selection experiment in pigs. II. Genetic changes and realized genetic parameters in the traits under selection. Acta Agr. Scand. 29:305.

Vangen, O. 1980. Studies on a two trait selection experiment in pigs. IV. Estimated maintenance requirements from feeding experiments. Acta Agr. Scand. 30:143.

Vanschoubroek, F., R. DeWilde and P. Lampo. 1967. The quantitative effects of feed restriction in fattening pigs on weight gain, efficiency of feed utilization and backfat thickness. Anim. Prod. 9:67.

Williams, C. H., D. J. David and O. lismaa. 1962. The determination of chromic oxide in faeces samples by atomic absorption spectrophotometry. J. Agr. Sci. (Camb.) 59:381. 